\title{
Modelling the impact of changing the decision to graze from rotation length to ryegrass leaf-stage
}

\author{
P.C. BEUKES, J.M. LEE, J.A.S. LANCASTER and J.R. ROCHE \\ Dexcel, PB 3221, Hamilton \\ pierre.beukes@dexcel.co.nz
}

\begin{abstract}
We used modelling to test the hypothesis that rotation length based on the emergence of three live leaves per ryegrass tiller (3-leaf principle) would result in greater pasture production, and increased milk production and profit per hectare than rotations based on standardised decision rules (best management practice; BMP). This hypothesis was tested using a computer program designed to model the interactions between climate, paddocks, animals and management policies. The model was set up for a farmlet (Strain Trial, Herd 1, 04/05 season) and simulated over 10 different climate years (93/94-02/03), two different sets of rotation lengths (3leaf and BMP), and over a range of comparative stocking rates $(85-100 \mathrm{~kg} \mathrm{Lwt} / \mathrm{t} \mathrm{DM})$. Average return on assets (ROA) was measured with random price sets drawn for milk, the variable cost of purchasing silage, and land appreciation rate. For the systems and climate years tested in this exercise the model predicted a greater $(\mathrm{P}<0.05)$ average ROA for BMP rotations compared to 3-leaf rotations (9.85 and 9.73\%/year, respectively). The 3leaf rotations resulted in a small $(\mathrm{P}<0.001)$ increase in pasture grown $(0.17 \pm 0.02$ t DM/ha). However, BMP scenarios were more profitable because of greater annual milksolids production per hectare (1\%), mainly achieved during peak lactation. The 3-leaf principle showed benefits in the second half of the season, but this could not compensate for the earlier loss in production.
\end{abstract}

Keywords: dairy farm system, grazing management, rotation length, whole farm model.

\section{Introduction}

Criteria for determining when to defoliate pasture have traditionally been based on day rotations, sward surface height and herbage mass, and have been used together with number of animals, paddock number and size, and feed allocation principles to develop best management practices for grazing stock (Fulkerson \& Donaghy 2001). These are all animal-related parameters. An alternative approach to grazing management is to base it on plantrelated indicators associated with maximising pasture regrowth and persistence.

Research has established that the rate of regrowth of perennial ryegrass (Lolium perenne L.) pasture follows a sigmoidal curve (Brougham 1957; Voisin 1959). This curve has three distinct phases, beginning with a slow recovery phase, then a period of exponential growth, followed by growth rate decline, slowly at first (due to the onset of senescence and shading) and then accelerating until growth stops (Brougham 1956, 1957). One study recorded that only $10 \%$ of the final DM yield was grown during the first phase, with approximately 32 and 58\% grown during the second and third phases respectively (Voisin 1959).

The three phases of pasture growth tend to correlate with the number of new leaves that have emerged on each ryegrass tiller, with relatively slow regrowth up to full expansion of the first new leaf, followed by a more rapid growth until leaf senescence begins after emergence of the third leaf(Fulkerson \& Slack 1994). This indicates that ryegrass pastures achieve maximum biomass accumulation when between 3 and 3.5 new leaves have emerged on individual plants (3-leaf principle; Fulkerson \& Donaghy 2001). Fulkerson \& Donaghy (2001) quote a number of studies showing that rotation lengths based on the 3-leaf principle not only maximise pasture growth and persistence, but also optimise the level of most of the nutrients required by dairy cattle. In the Waikato region of New Zealand, between September and April, emergence of the third new leaf occurs on average 16 days later than "best management practice" (BMP) recommended rotations of 24 days (J.M. Lee \& J.R. Roche, unpublished). This means that BMP pastures are grazed during the period of exponential growth (before emergence of the second new leaf), and potentially results in a substantial loss in pasture production.

However, rotation length not only impacts on the amount of pasture grown, but may also affect animal intake, milk production (Da Silva et al. 1994), and ultimately farm profitability (Penno et al. 1995). Before recommending different rotation lengths it is important to evaluate the biological and financial impacts on the whole system. It is also important to realise that outcomes may be dependent on year (climate) and farm system, and that generalised rules may not always be applicable. This multi-factorial dependency makes this an ideal question for computer modelling, allowing the complex interactions between management, climate, pastures and animals to be investigated.

Dexcel's Whole Farm Model (WFM) was used to evaluate the merits of the two different approaches to grazing management (3-leaf versus BMP) across 
different farm systems and climate years in terms of farm physical and financial indicators.

\section{Methods}

\section{Basic model set-up}

The Whole Farm Model (WFM) version 1.0.7 was used for this exercise (see Beukes et al. (2005a) for more detail about the WFM and its use). Pasture growth in the WFM was driven by weather data (daily rainfall, radiation and temperature supplied by NIWA) from Ruakura Climatological Station, using the pasture growth model of McCall \& Bishop-Hurley (2003). Pasture quality is not predicted by the model but is a user setting on a monthly basis (default average over the year is $11 \mathrm{MJ}$ $\mathrm{ME} / \mathrm{kg} \mathrm{DM}$ ). Grass silage quality is also a user setting at a default of 10 MJ ME/kg DM. "Molly" (Baldwin 1995; version 4.16) was the cow model used.

A modelled farmlet of 6 ha with 12 paddocks $(0.5 \mathrm{ha} /$ paddock) was set up representing a typical all-pasture Waikato farm. Information describing this typical farm was obtained from Dexcel's Holstein-Friesian Strain Trial, herd 1 (High-BW NZ genetics stocked at 3.3 cows/ ha with a projected pasture allowance of $5 \mathrm{t} \mathrm{DM/cow),}$ for the 2004/05 season. Individual paddocks were initialised using observed covers at the beginning of the season (1 June), and individual cows (20) were initialised using observed age, liveweight (Lwt) and condition score at 1 June, and observed calving and dry-off dates for the 2004/05 season. Production Value for milk (PVmilk) and age were used to initialise the genetic potential of the cows; PVmilk $=1259 \mathrm{~L} /$ year for $4+$ years, PVmilk = $1355 \mathrm{~L} /$ year for 3 years, PVmilk $=985 \mathrm{~L} /$ year for 2 years (Beukes et al. 2006). The model was set up with Strain Trial management policies for post-grazing residuals (> $1200 \mathrm{~kg} \mathrm{DM} / \mathrm{ha}$ ), conservation and cutting of paddocks, fertiliser application (170 kg N/ha/yr) and mating of the herd. Both dry cows and milkers were fed pasture up to demand if available according to the prescribed break size and minimum residual. If there was a pasture deficit on a specific day then grass silage was fed up to a maximum of $7 \mathrm{~kg} \mathrm{DM} / \mathrm{cow} /$ day. Silage was fed from a feed store allowing for wastage of $10 \%$. After cutting, silage was also added to the feed store accounting for ensiling losses of $15 \%$. For this exercise the start feed store was set at $50 \mathrm{t} \mathrm{DM}$ to ensure that the farm never ran out of silage even in the worst climate years.

\section{Rotation policies}

The model simulates a farm on a daily time step, rotating the dry and milking cow herds separately according to a user-specified rotation policy. The user's specifications are applied in 10-day blocks. From the first calving date to the balance date (i.e. the date when pasture supply is expected to exceed demand) the model over-rides any other rotation settings by implementing the spring rotation planner. The planner is implemented by linearly reducing the rotation length from the setting at first calving to the setting at balance date. For this exercise the balance date was set at 15 September.

Two sets of rotation lengths were implemented in the basic scenario. The first set followed the observed rotations as implemented in the Strain Trial, which was defined as "best management practice" (BMP), whereas the second was based on the number of days required for three live leaves to emerge on ryegrass tillers (3-leaf principle). The rate of leaf emergence was determined weekly on pastures adjacent to the Strain Trial, using the method outlined by Fulkerson \& Donaghy (2001). Average rotation lengths from 15 September to 30 April were 24 and 40 days for the BMP scenario and 3-leaf scenario, respectively.

To compare the biological and financial impacts of rotation length across farm systems with different feed allowances, stocking rate was varied by randomly replicating cows in the original herd of 20 cows to obtain herds of 22 and 23 cows, and by dropping cows randomly from the original herd to obtain herds of 18 and 16 cows. This resulted in five scenarios for each of the rotation sets with stocking rates varying from 2.7 to $3.8 \mathrm{cows} / \mathrm{ha}$, i.e. comparative stocking rates varying from approximately 85 to $100 \mathrm{~kg} \mathrm{Lwt} / \mathrm{t} \mathrm{DM}$.

\section{Economic analysis}

The WFM simulates a scenario for a year and then uses the production data together with user-defined economic inputs to produce an economic report with a calculated Economic Farm Surplus (EFS, \$/ha) and Return on Assets (ROA). The EFS calculation is adjusted for the differences in farm cover and supplement on hand (i.e. difference between opening and closing stock) and cow condition at the end of the simulation.

Default economic input values were used for this exercise and were derived from economic farm survey data (Dexcel 2005). Silage making and feeding were important activities in all the scenarios and costs were set at \$100/t DM for making silage and \$30/t DM for feeding silage. For the economic analysis, each scenario ( 2 rotations $\times 5$ stocking rates $=10$ scenarios) was simulated for each of 10 climate years (1993/94 - 2002/ 03). The modelled production for each season together with a set of 100 random combinations of prices were used to calculate 100 possible ROA's for each system for each season. These prices were sampled using the Monte Carlo technique, assuming a normal distribution (average \pm standard deviation) with price per $\mathrm{kg}$ milksolids ( $\$ 3.90 \pm \$ 1.00)$, cost of supplement $(\$ 200 \pm \$ 50$ per $\mathrm{t} \mathrm{DM})$, and land appreciation rate $(4 \% \pm 5 \%)$ (Neal 
Table 1 Predicted means of farm physical parameters. SED and P-values of treatment effects are also indicated.

\begin{tabular}{lcccccc}
\hline $\begin{array}{l}\text { Farm physical } \\
\text { parameter }\end{array}$ & $\begin{array}{c}\text { BMP } \\
\text { rotations }\end{array}$ & $\begin{array}{c}\text { 3-leaf } \\
\text { rotations }\end{array}$ & $\begin{array}{c}\text { SED } \\
\text { rotation } \\
\text { policy }\end{array}$ & $\begin{array}{c}\text { P-value } \\
\text { rotation } \\
\text { policy }\end{array}$ & $\begin{array}{c}\text { P-value } \\
\text { stocking } \\
\text { rate }\end{array}$ & $\begin{array}{c}\text { P-value } \\
\text { interaction }\end{array}$ \\
\hline Annual pasture production (t DM/ha) & 17.0 & 17.2 & 0.02 & $<0.001$ & $<0.001$ & 0.84 \\
Farm cover change (kg DM/ha) & 287 & 427 & 71.8 & 0.08 & $<0.001$ & $<0.001$ \\
Silage made (t DM/ha) & 1.78 & 1.85 & 0.054 & 0.23 & $<0.001$ & 0.39 \\
Silage fed (t DM/ha) & 3.26 & 3.37 & 0.04 & $<0.05$ & $<0.001$ & 0.06 \\
Pasture intake (kg DM/cow) & 4359 & 4339 & 9.6 & 0.07 & $<0.001$ & 0.06 \\
Silage intake (kg DM/cow) & 864 & 896 & 10.8 & $<0.05$ & $<0.001$ & $<0.05$ \\
Total intake (kg DM/cow) & 5223 & 5235 & 10.9 & 0.28 & $<0.001$ & $<0.05$ \\
Milksolids $(\mathrm{kg} / \mathrm{ha})$ & 1384 & 1370 & 1.7 & $<0.001$ & $<0.001$ & $<0.001$ \\
Liveweight change $(\mathrm{kg})$ & -23 & -14 & 1.8 & $<0.001$ & $<0.001$ & 0.98 \\
\hline
\end{tabular}

2004). Because supplement prices are correlated with climate year, the normal distribution for supplement purchase cost was adjusted up or down depending on the pasture production of a year $(\$ 26 / \mathrm{t} \mathrm{DM})$. Prices were less in good pasture growth years and greater in poor years.

\section{Data analysis}

Data were analysed using analysis of variance, with rotation length, stocking rate and their interactions as treatment factors, and climate year and the treatment factors within climate years as blocks. The Genstat 8.2 package was used. Some farm physical parameters were averaged for good (1995/96, 19t DM/ha), average (1997/ $98,16 \mathrm{t} \mathrm{DM} / \mathrm{ha})$ and poor $(1994 / 95,15 \mathrm{t} \mathrm{DM} / \mathrm{ha})$ pasture growth seasons and graphed over time in an attempt to visualise the impacts of rotation length policy.

\section{Results}

The 3-leaf rotations resulted in a small increase $(\mathrm{P}<0.001)$ in pasture production $(0.17 \mathrm{t} \mathrm{DM} /$ ha; Table 1$)$. Silage fed and silage intake was also greater for the 3-leaf rotations compared to BMP rotations. In comparison BMP rotations resulted in greater milksolids (MS) production (14 kg/ha) and greater Lwt change compared to 3-leaf rotations (Table 1).

Stocking rate showed a significant effect on all of the measured farm physical parameters, and had significant interactions with rotation policy regarding farm cover change, silage and total intake and MS (Table 1). As stocking rate increased, the differences in cover change between the rotation policies were reduced, but the differences in milksolids production increased in magnitude.

Milksolids production was higher with BMP rotations irrespective of climate year because cow intake of pasture was higher during the early part of lactation (Fig. 1), requiring less silage feeding during this critical time, and resulting in higher milksolids production during peak lactation (Fig. 2). Cows were generally fed better in the second half of the season with the 3-leaf rotations (Fig. 3 ), resulting in small gains in terms of MS and Lwt.

Figure 1 Predicted pasture intake during a good pasture growth year (1995/96, 19 t DM/ha) with BMP rotations (dark line) and 3-leaf rotations (shaded line).

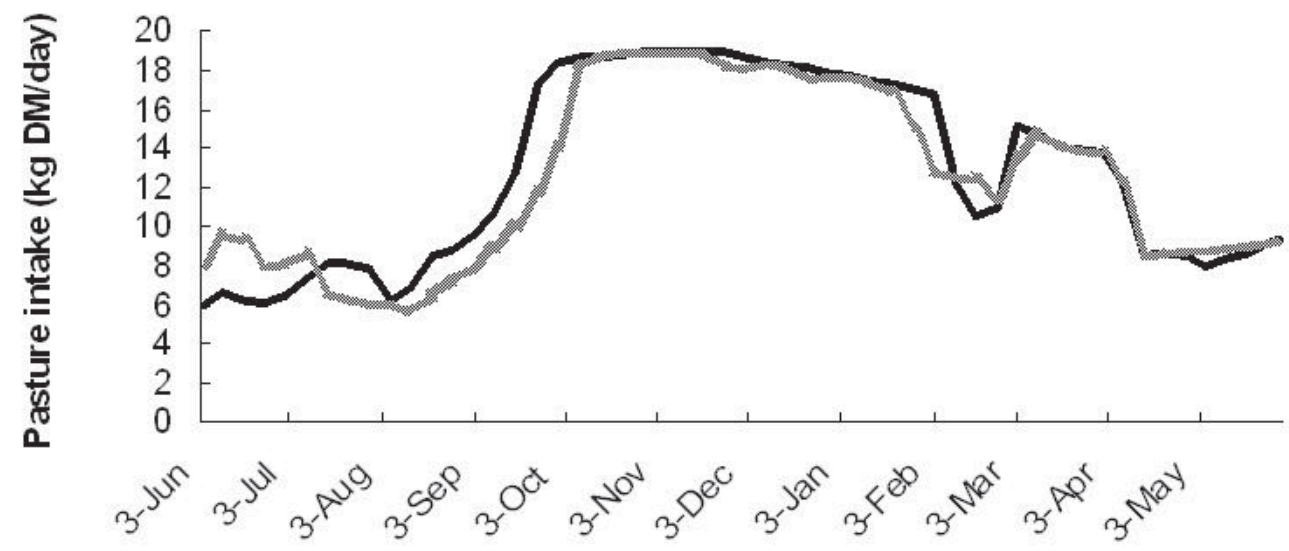


Figure 2 Predicted milksolids production during a good pasture growth year (1995/96, 19 t DM/ha) with BMP rotations (dark line) and 3 -leaf rotations (shaded line). Averages were calculated by aligning cows according to week of lactation.

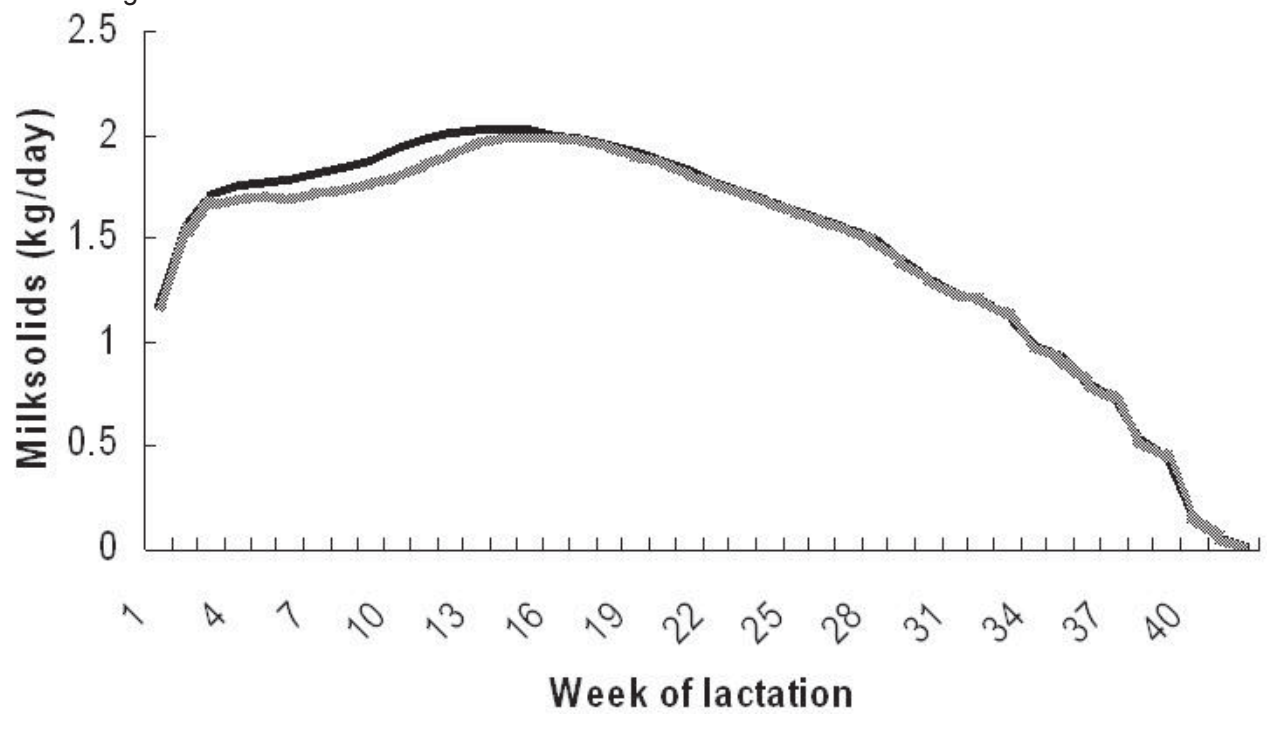

Figure 3 Predicted feed intake during a poor pasture growth year (1994/95, 15 t DM/ha) with BMP rotations (dark line) and 3-leaf rotations (shaded line).

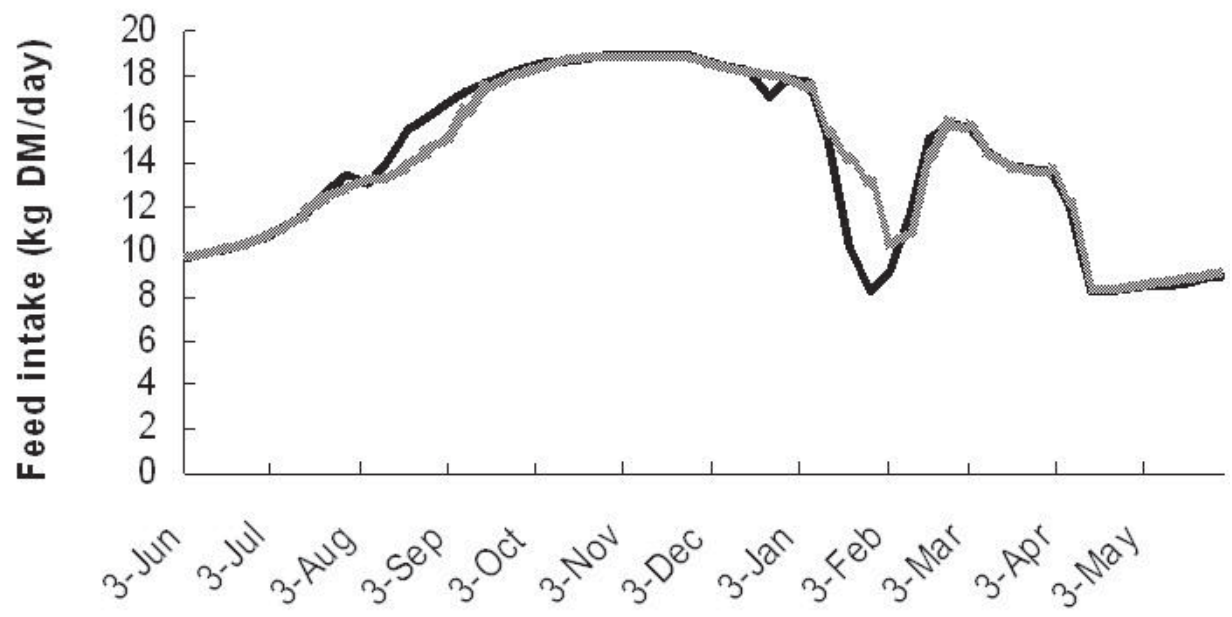

Date

For both rotation length policies ROA increased as stocking rate increased up to the maximum ROA at 3.3 cows/ha (approximately $95 \mathrm{~kg} \mathrm{Lwt} / \mathrm{t}$ DM feed), declining again at higher stocking rates (Fig. 4). For the systems and climate years tested in this exercise the model predicted a greater $(\mathrm{P}<0.05)$ average ROA for BMP rotations of $9.85 \% / \mathrm{yr}$ compared with $9.73 \% / \mathrm{yr}$ for 3leaf rotations.

\section{Discussion}

In the current study, defoliation of pasture at the 3-leaf stage increased pasture production by only $1 \%$, compared with pastures defoliated before emergence of the second new leaf (BMP), a smaller response than was expected. When Fulkerson et al. (1993) extended the defoliation interval from 2 or 4 weeks to defoliation at the 3-leaf stage, annual pasture production was increased by 32 or $12 \%$, respectively. A major factor influencing pasture regrowth is the level of stored energy (water-soluble carbohydrates; WSC) in the plants. Immediately following defoliation, WSC reserves are utilised for new shoot growth (Fulkerson \& Donaghy 2001). When one 
Figure 4 Predicted average return on assets for farm systems with different stocking rates and BMP rotations (shaded bars) and 3-leaf rotations (blank bars).

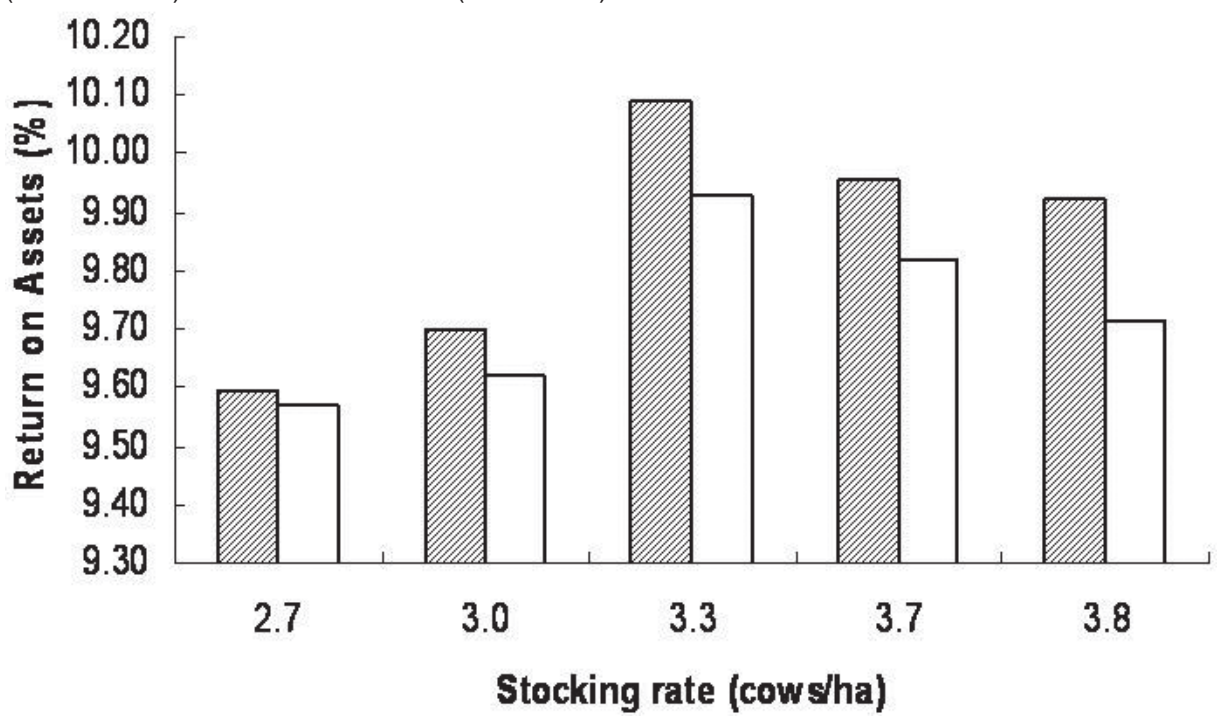

new leaf has emerged, the plant has adequate photosynthetic capacity for growth, and replenishment of WSC reserves begins, rising linearly with leaf number (Fulkerson \& Slack 1994). Consistent defoliation of pasture before emergence of the third new leaf may have reduced pasture production because of incomplete replenishment of WSC, and less available energy for subsequent regrowth. The pasture growth model of McCall \& Bishop-Hurley (2003) does not include energy reserves as a factor in pasture growth, and therefore has no feedback mechanism where low WSC levels reduces pasture production and persistence. This may be one explanation for the small response in pasture production measured in the current study.

Alternatively, the small increase in pasture yield predicted for the 3-leaf rotations may be a more realistic result for a farm system over a full season compared to the higher expectations generated by short-term, smallscale cutting experiments. Firstly, there is a limited time in the year when pasture growth rate is steep enough for intervals between defoliations to make a large impact on biomass accumulation. The second reason relates to the statement by Matthews et al. (1999) that rotation length describes the current rate of movement around the farm, and does not necessarily describe the interval between successive grazings. The model showed that the outcome of the rotation policy on the defoliation frequency of a specific paddock over a specific time was influenced by the interaction of the number of herds on the farm, conservation and cutting policy, paddock selection policy, grazing residual policy and pasture growth rate. Frequency of defoliation in a farm system is not as tightly controlled as in a cutting experiment, resulting in substantial variation in defoliation frequency amongst paddocks and over time. In a system, few paddocks are actually defoliated at the optimum frequency. However, it does remain important that further research is done to ensure WFM is adequately predicting pasture grown under very long rotations.

The results presented here emphasise the importance of feed quantity and quality during peak lactation, and more specifically the period after balance date (15 September) in early spring. Model predictions indicated that cows were given more feed after the balance date with BMP rotations compared to scenarios with 3-leaf rotations. Quality of feed eaten during spring was also increased with BMP rotations because pasture intake was higher and silage intake lower, and generally grass silage has lower nutritional value than spring pasture (Holmes et al. 2002). In another modelling exercise, Beukes et al. (2005b) found that an earlier breakeven (= balance) date (25 September) was more profitable compared to a later breakeven date (20 October). The earlier date resulted in shorter rotation lengths earlier in the season with the consequence that lactating cows obtained a larger proportion of their demand from higher quality pasture and could be fed less grass silage.

In most instances the decision to alter rotation length is associated with a decision to alter the pasture intake level per animal, intakes increasing when the grazing rotation is shortened and decreasing when the rotation is lengthened (Matthews et al. 1999). Our results support the findings of Bryant (1990) that short rotations (19-25 days) in early spring increased feeding levels and production after calving, but reduced average pasture cover, slowed pasture growth rate and resulted in poorer 
feeding of the herd in late spring. Modelled results of the poor pasture growth year $(1994 / 95,15$ t DM/ha) specifically showed the negative effects of short rotations in early spring, i.e. slower growth rates and lower covers and then poorer feeding of the herd in late spring. Our results also support the other conclusion of Bryant (1990) that long spring rotations penalised feeding levels and production in early lactation more than was compensated for by having extra pasture available in late spring.

Grazing rotations can be used as a means of transferring pasture from times of fast growth to times of slower growth by allowing farm covers to increase or by conservation and silage making (Matthews et al. 1999). Less frequent defoliation regimes during spring (i.e. 3-leaf rotations) compared to conventional frequent spring grazing (BMP rotations) can have benefits to farm production in the second half of the season. This approach to spring grazing management has been called "late control" (Matthew 1991). Late control could be implemented by either a delay in shutting paddocks for conservation or longer rotations plus the strategic use of supplementation in early spring to decrease grazing pressure on pastures (Da Silva et al. 1994). In paddock scale experiments Da Silva et al. (1994) found that late control resulted in increased pasture production and postulated that on a farm scale this could result in increased farm covers that could potentially be converted into either increased milksolids per day or longer lactations. In a self-contained farm system experiment, however, Bishop-Hurley et al. (1997) found that late control spring grazing management did not significantly increase pasture or milksolids production within the confines of a closed production system. Penno et al. (1995) changed rotation length in early January from short (16 day) to long (40 day) and found an immediate decrease in animal performance because animals were forced to eat old pasture, but the benefits of the long rotations came through as a higher pasture production over the second half of the season, increased milksolids production, higher farm covers and cow condition by April. Our results confirmed the general hypothesis that less frequent grazing (e.g. 3-leaf rotations) in the early part of the season should generate benefits in the second half of the season. The model specifically showed this for the 3-leaf scenarios in the average (1997/98, $16 \mathrm{t} \mathrm{DM/ha)} \mathrm{and} \mathrm{poor} \mathrm{(1994/95,} 15 \mathrm{t}$ $\mathrm{DM} / \mathrm{ha}$ ) pasture growth years with higher farm covers leading to better feeding of cows, more milksolids production and greater liveweights in the second half of the season. However, we also showed that, on average, the benefits that accrued in the second half of the season, when converted into monetary terms, could not compensate for the lower milksolids production in the first half of the season.
Our results further support the recommendation by Penno (1998) that longer rotations (30-40 day) in late spring could be adopted if a dry summer is expected. In the current study, longer (3-leaf) rotations resulted in $2 \%$ more milksolids and $2 \%$ higher live weight over the second half of the poor pasture growth year (1994/95, $15 \mathrm{t} \mathrm{DM} / \mathrm{ha}$ ) compared to the shorter rotation (BMP) scenario. It is important to achieve good pasture utilisation to convert the extra pasture into milksolids, and as Simons et al. (1998) reported, the benefits may only come at the end of the season when cows can be milked for longer. A factor that was not modelled, but needs to be considered, is the likelihood of a decrease in pasture quality when farm covers are allowed to increase in late spring/early summer. Once the stem-to-leaf ratio increases, the digestibility and metabolisable energy content of the feed rapidly declines (Macdonald 1997). Conservation methods should be used to harvest any excess pasture and to maintain feed quality.

\section{Conclusions}

On average, over different climate years and stocking rates, BMP rotations were marginally more profitable compared to 3-leaf rotations. The shorter rotations resulted in better feeding and more milksolids production in the first half of the season. The benefits of the longer 3-leaf rotations accrued in the second half of the season, but could not compensate, in monetary terms, for the earlier losses in milksolids production. There does, however, appear to be merit in less frequent grazing (longer rotations) in late spring when a dry summer is expected. With proper utilisation the extra herbage mass transferred into summer-autumn could be converted into more milksolids and better cow condition.

\section{ACKNOWLEDGEMENTS}

This study was funded by Dairy InSight (project 10079).

\section{REFERENCES}

Baldwin, R.L. 1995. Modelling ruminant digestion and metabolism. Chapman \& Hall, London. 578 pp.

Beukes, P.; Palliser, C.; Lancaster, J.; Leydon-Davis, C.; Levy, G.; Folkers, C.; Macdonald, K.; Thorrold, B.; Montgomerie, B.; Wastney, M. 2006. Predicting cow production based on an estimate of animal genotype within a Whole Farm Model. Proceedings of the New Zealand Society of Animal Production 66: 93-97.

Beukes, P.C.; Palliser, C.C.; Prewer, W.; Serra, V.; Lancaster, J.A.S.; Levy, G.; Folkers, C.; Neal, M.; Thorrold, B.S.; Wastney, M.E. 2005a. Use of a Whole Farm Model for Exploring Management Decisions in Dairying. pp. 177-183. In: Eds. Zerger, A.; Argent, R.M. MODSIM 2005 International Congress on 
Modelling and Simulation. Modelling and Simulation Society of Australia and New Zealand.

Beukes, P.C.; Thorrold, B.S.; Wastney, M.E.; Palliser, C.C.; Levy, G.; Chardon, X. 2005b. Modelling the effect of breakeven date in spring rotation planner on production and profit of a pasture-based dairy system. p. 881. In: Proceedings of the XX International Grassland Congress: Offered papers, Wageningen Academic Publishers.

Bishop-Hurley, G.J.; Matthews, P.N.P.; Hodgson, J.; Dake, C.; Matthew, C. 1997. Dairy systems study of the effects of contrasting spring grazing managements on pasture and animal production. Proceedings of the New Zealand Grassland Association 59: 209-214.

Brougham, R.W. 1956. Effect of intensity of defoliation on regrowth of pastures. Australian Journal of Agricultural Research 7: 377-387.

Brougham, R.W. 1957. Pasture growth rate studies in relation to grazing management. Proceedings of the New Zealand Society of Animal Production 17: 46-55.

Bryant, A.M. 1990. Present and future grazing systems. Proceedings of the New Zealand Society of Animal Production 50: 35-38.

Da Silva, S.C.; Hodgson, J.; Matthews, P.N.P.; Matthew, C.; Holmes, C.W. 1994. Effect of contrasting spring grazing management on summer-autumn pasture and milk production of mixed ryegrass-clover dairy swards. Proceedings of the New Zealand Society of Animal Production 54: 79-82.

Dexcel Ltd. 2005. Economic survey of New Zealand dairy farmers, 2003-2004. Hamilton. 36 pp.

Fulkerson, W.J.; Donaghy, D.J. 2001. Plant-soluble carbohydrate reserves and senescence - key criteria for developing an effective grazing management system for ryegrass-based pastures: a review. Australian Journal of Experimental Agriculture 41: 261-275.

Fulkerson, W.J.; Slack, K. 1994. Leaf number as a criterion for determining defoliation time for Lolium perenne. 1 . Effect of water-soluble carbohydrates and senescence. Grass and Forage Science 49: 373-377. Fulkerson, W.J., Slack, K., Moore, K.; Rolfe, C. 1993.
Management of Lolium perenne/Trifolium repens pastures in the subtropics. I. Effect of defoliation interval, seeding rate and application of $\mathrm{N}$ and lime. Australian Journal of Agricultural Research 44: $1947-$ 1958.

Holmes, C.W.; Brookes, I.M.; Garrick, D.J.; Mackenzie, D.D.S.; Parkinson, T.J.; Wilson, G.F. 2002. Milk production from pasture. Principles and practices. Massey University, Palmerston North, New Zealand. 602 pp.

Macdonald, K.A. 1997. Profitable Dairying. NZ Rural Press Limited.

Matthew, C. 1991. "Late Control" - What is it, and why should it work? Dairyfarming Annual, Massey University 43: 37-42.

Matthews, P.N.P.; Harrington, K.C.; Hampton, J.G. 1999. Management of grazing systems. pp. 153-174. In: New Zealand Pasture and Crop Science. Eds. White, J.; Hodgson, J. Oxford University Press.

McCall, D.G.; Bishop-Hurley, G.J. 2003. A pasture growth model for use in a whole-farm dairy production model. Agricultural Systems 76: 1183-1205.

Neal, M. 2004. Optimising return in a whole-farm model under conditions of risk. Proceedings of the Annual Australian Agricultural and Resource Economics Conference 48: 1-19.

Penno, J.W.; Bryant, A.M.; Carter, W.A.; Macdonald, K.A. 1995. Effect of nitrogen fertiliser and summer rotation length on milk production in a dry Waikato summer. Proceedings of the New Zealand Society of Animal Production 55: 64-66.

Penno, J.W. 1998. Principles of profitable dairying. pp. 1-14. In: Proceedings of the 50th Ruakura Farmers' Conference.

Simons, H.P.; Thomson, N.A.; McGrath, D.F.; Dawson, J.E. 1998. More summer milk - a further investigation into improving summer milk production. Proceedings of the New Zealand Grassland Association 60: 2731.

Voisin, A. 1959. Grass Productivity. Philosophical Library Inc., New York, USA. 